\title{
The p38alpha mitogen-activated protein kinase limits the CNS proinflammatory cytokine response to systemic lipopolysaccharide, potentially through an IL-10 dependent mechanism
}

\author{
Adam D Bachstetter ${ }^{1}$, Bin Xing ${ }^{1,3}$ and Linda J Van Eldik ${ }^{1,2^{*}}$
}

\begin{abstract}
Background: The p38a mitogen-activated protein kinase (MAPK) is a well-characterized intracellular kinase involved in the overproduction of proinflammatory cytokines from glia. As such, p38a appears to be a promising therapeutic target for neurodegenerative diseases associated with neuroinflammation. However, the in vivo role of p38a in cytokine production in the CNS is poorly defined, and prior work suggests that p38a may be affecting a yet to be identified negative feedback mechanism that limits the acute, injury-induced proinflammatory cytokine surge in the CNS.

Methods: To attempt to define this negative feedback mechanism, we used two in vitro and two in vivo models of neuroinflammation in a mouse where p38a is deficient in cells of the myeloid lineage.

Results: We found that p38a in myeloid cells has an important role in limiting amplitude of the acute proinflammatory cytokine response to a systemic inflammatory challenge. Moreover, we identified IL-10 as a potential negative feedback mechanism regulated by p38a.

Conclusions: Our data suggest that p38a regulates a proper balance between the pro- and anti-inflammatory cytokine responses to systemic inflammation, and that if circulating IL-10 levels are not elevated to counter-balance the increased systemic proinflammatory responses, the spread of the inflammatory response from the periphery to the CNS is exaggerated.
\end{abstract}

Keywords: cytokines, glia, interleukin, neuroinflammation, signal transduction, tumor necrosis factor alpha

\section{Introduction}

Inflammation is a complex response that requires tight regulatory control of its initiation and resolution. In the central nervous system (CNS), neuroinflammation has gained increasing support as a contributing mechanism in a number of neurodegenerative diseases [1,2], including Alzheimer's disease (AD) [3] and Parkinson's disease [4], as well as acute neurodegenerative conditions such as traumatic brain injury (TBI) [5], spinal cord injury [6] and stroke [7]. As one aspect of neuroinflammation, proinflammatory cytokines have been linked to tissue injury and

\footnotetext{
* Correspondence: linda.vaneldik@uky.edu

${ }^{1}$ Sanders-Brown Center on Aging, University of Kentucky, 800 S. Limestone

Street, Lexington, KY 40536, USA

${ }^{2}$ Department of Anatomy and Neurobiology, University of Kentucky, $800 \mathrm{~S}$.

Limestone Street, Lexington, KY 40536, USA

Full list of author information is available at the end of the article
}

disease processes $[8,9]$. For example, overproduction of IL$1 \beta$ by activated microglia can induce pathological tau phosphorylation and a decline in synaptophysin levels in neurons $[10,11]$. Cytokine production is regulated at multiple levels; however, one intracellular mechanism involved in upregulated cytokine production is the p38 mitogenactivated protein kinase (MAPK). The p38 MAPK family consists of at least four isoforms $(\mathrm{p} 38 \alpha, \beta, \delta, \gamma)$, which are encoded by separate genes, expressed in different tissues and cell types, and are often functionally distinct [12]. Mechanistically, the p38 MAPKs phosphorylate protein substrates that are downstream targets involved in the regulation of proinflammatory cytokine gene expression through effects on transcription and translation (for review see: [12]).

Since the discovery of the pyridinyl imidazole class of small molecule anti-inflammatory compounds that inhibit 
the activity of p38 (commonly known as 'SB' compounds) [13], extensive resources have been allocated to the development and refinement of p38 inhibitors for the treatment of peripheral inflammatory diseases [14,15]. A few studies have used small molecule p38 inhibitors in vivo to demonstrate that pharmacological inhibition of p38 $\alpha$ is neuroprotective in animal models of CNS disorders, such as AD [16,17], global and focal ischemia [18-21], neuropathic pain [22], and seizures [23]. However, human clinical trial experience with $\mathrm{p} 38 \alpha$ inhibitors has yielded mixed results. Published data on the effects of p38 inhibition in cardiovascular disease, chronic obstructive pulmonary disease, and neuropathic pain show encouraging results, whereas trials in rheumatoid arthritis and Crohn's disease show limited, if any, efficacy (for review see: [24]). These results emphasize the importance of a better understanding of the in vivo role of $\mathrm{p} 38 \alpha$ in various inflammatory diseases, especially neuroinflammatory disorders of the CNS.

While p38 $\alpha$ appears promising as a therapeutic target for neurodegenerative diseases $[17,25,26]$, more preclinical work is necessary to determine the appropriate disease indications, therapeutic window, and potential side effects of inhibiting the p $38 \alpha$ pathway. For example, in vitro studies have demonstrated that the $\mathrm{p} 38 \alpha$ isoform contributes to approximately $50 \%$ of the IL-1 $\beta$ and TNF $\alpha$ produced by microglia in response to inflammatory stimuli [27]. In contrast, following a diffuse TBI in mice with a genetic knockdown of $\mathrm{p} 38 \alpha$ in cells of the myeloid lineage (p38 $\alpha^{\Delta \text { LysM-Cre }} \mathrm{KO}$ mice), an enhanced CNS acute cytokine surge (more IL-1 $\beta$, IL-6, TNF $\alpha$ ) was found at $6 \mathrm{hr}$ postinjury; however by 7 days post-injury, cytokine levels in the p38 $\alpha^{\Delta \text { LysM-Cre }}$ KO mice were below that of the injured wild-type (WT) mice [28]. These results suggest that p38 $\alpha$ may be affecting a yet to be identified negative feedback mechanism that limits the acute cytokine surge occurring during the first hours after an in vivo insult, which is not evident in vitro. The goal of this project was to explore the potential mechanism by which p38 $\alpha$ could suppress the acute proinflammatory cytokine response in the CNS. We report here that the CNS proinflammatory response to systemic lipopolysaccharide (LPS) administration is enhanced in the $\mathrm{p} 38 \alpha^{\Delta \mathrm{LysM}-\mathrm{Cre}} \mathrm{KO}$ mice compared to WT mice, and that $\mathrm{p} 38 \alpha$ is required by myeloid cells to produce IL-10 in response to LPS. Our results suggest that $\mathrm{p} 38 \alpha$ has a critical role in limiting the spread of the peripheral inflammatory response to the CNS through regulating the production of the anti-inflammatory cytokine IL-10.

\section{Materials and methods Reagents}

Lipopolysaccharides (LPS) from Salmonella enterica serotype typhimurium (Sigma-Aldrich, St. Louis, MO, USA: Cat. no. L6143-1MG; EU/MG of LPS is 600,000) was prepared in sterile $0.9 \%$ sodium chloride that was free of preservatives (Hospira, Inc., Lake Forest, IL: cat. no. NDC 0409-4888-10). Sterile 0.9\% sodium chloride was used as the vehicle (veh) control in all experiments.

\section{Animals}

Experiments were conducted in accordance with the principles of animal care and experimentation in the Guide For the Care and Use of Laboratory Animals. The Institutional Animal Care and Use Committee of the University of Kentucky approved the use of animals in this study (protocol \#2010-0615). The p38 $\alpha^{\Delta \text { LysM-Cre }}$ KO mice were generated as previously described [29]. The first exon of the p38 $\alpha$ gene (MAPK14) was flanked by two loxP sites. The $\mathrm{p} 38 \alpha$ floxed mice were maintained as homozygotes: $\mathrm{p} 38 \alpha^{\mathrm{fl} / \mathrm{fl}}$. To induce cell-specific deletion of $\mathrm{p} 38 \alpha$ MAPK in myeloid cells including macrophages and microglia, the $\mathrm{p} 38 \alpha^{\mathrm{fl} / \mathrm{fl}}$ mice were crossed with mice that contain Cre driven by the lysozyme promoter. The restricted cell-type expression of the lysozyme promoter $[30,31]$ results in myeloid cell-specific deletion, as we have previously validated $[27,28,32]$. The mice were backcrossed to generate mice that were null for mouse WT p38 $\alpha$, homozygous for floxed p38 $\alpha$, and hemizyogous for LysM-Cre: $\mathrm{p} 38 \alpha^{\mathrm{fl} / \mathrm{fl} ; \mathrm{LysM}-\mathrm{Cre}}$. The $\mathrm{p} 38 \alpha^{\mathrm{fl} / \mathrm{fl}}$ were crossed with the $\mathrm{p} 38 \alpha^{\mathrm{fl} / \mathrm{fl} ; \mathrm{LysM}-\mathrm{Cre}}$ to generate litters where approximately $50 \%$ of the mice are microglia/macrophage conditional p38 $\mathrm{KO}\left(\mathrm{p} 38 \alpha^{\Delta \mathrm{LysM}-\mathrm{Cre}} \mathrm{KO}\right)$ and approximately $50 \%$ are $\mathrm{p} 38 \alpha^{\mathrm{fl} / \mathrm{fl}}$ littermates (used as WT controls). All experiments used both genders of mice at approximately a 50:50 ratio. Genotyping was performed by Transnetyx, Inc (Cordova, TN, USA). On the basis of preliminary data and prior published work [27], we find cytokine levels to be consistently below or at the limit of detection in unstimulated mice. Therefore, to reduce the total number of mice needed for the experiments, the number of mice treated with veh alone was kept to the minimum ( $\mathrm{n}=2$ per group/ time point) necessary to confirm there was no elevated basal cytokine response due to experimental manipulation or other idiopathic cause.

\section{Lipopolysaccharide administration}

For intracerebroventricular (ICV) administration of LPS, three to four month old male and female mice were anesthetized with $5 \%$ isoflurane prior to stabilizing the head using ear bars in a digital mouse stereotaxic frame (Stoelting Co, Wood Dale, IL, USA). Anesthesia was maintained with continuous inhalation of isoflurane $(3.5 \%$, 1 liter/min). A midline incision was made in the scalp to expose the skull. A hole was drilled into the skull over the right lateral ventricle at the following coordinates: $\mathrm{AP}=$ $-0.5 \mathrm{~mm} ; \mathrm{ML}=-1.0 \mathrm{~mm}$. With a $10-\mu \mathrm{l}$ Hamilton syringe with a blunt 28-gauge needle, veh or LPS was injected at the following coordinates: $\mathrm{AP}=-0.5 \mathrm{~mm} ; \mathrm{ML}=-1.0 \mathrm{~mm}$; 
DV $=-1.8 \mathrm{~mm}$. The Quintessential Stereotaxic Injector (Stoelting Co, Wood Dale, IL, USA) was used to inject $2 \mu \mathrm{l}$ at a rate of $0.5 \mu \mathrm{l}$ per min. After injection, the needle was left in place for 2 min before being slowly withdrawn. The incision was closed using staples, and the animal was kept on a heat pad until return of normal activity, at which time the mouse was returned to its home cage. Serum and brain tissues were harvested at $6 \mathrm{hr}$ after treatment. Intraperitoneal (IP) administrations of LPS (5 mg/ $\mathrm{kg}$ ) or veh were done as previously described [27]. Serum and brain tissues were harvested at 1,6 , and $24 \mathrm{hr}$ after treatment.

\section{Tissue collection and processing}

Mice were injected with an overdose of sodium pentobarbital (Pentasol powder; Vibrac Animal Health, Ft Worth, TX, USA: cat. no. NDC-051311-103-25). Blood was collected by cardiac puncture, prior to transcardiac perfusion with ice-cold phosphate buffered saline (PBS) for $5 \mathrm{~min}$. The mice were then decapitated. The brain was dissected on ice, snap-frozen in liquid nitrogen, and stored at $80^{\circ} \mathrm{C}$ until time of use. Brain tissue (cortex or hippocampus) was homogenized using high shear homogenizer, in a 1:10 (w/v) of ice-cold freshly prepared lysis buffer consisting of PBS containing $1 \mu \mathrm{g} / \mathrm{ml}$ Leupeptin, $1 \mathrm{mM}$ PMSF, and $1 \mathrm{mM}$ EDTA. The tissue homogenate was centrifuged at $14,000 \times g$ for $20 \mathrm{~min}$ at $4^{\circ} \mathrm{C}$ in a microcentrifuge, and supernatants were collected and stored at $-80^{\circ} \mathrm{C}$ until use.

\section{Microglia and mixed glia cultures}

Microglia cultures were prepared as previously described [32]. Briefly, mixed glial cultures (approximately 95\% astrocytes, approximately $5 \%$ microglia) were prepared from the cerebral cortices of 1 to 3 day old mice. The tissue was trypsinized, and the cells were resuspended in glia complete medium ( $\alpha$-minimum essential medium ( $\alpha$-MEM; Mediatech, Manassas, VA, USA) supplemented with $10 \%$ fetal bovine serum (FBS) (US Characterized FBS; Hyclone; Cat no. SH30071.03), $100 \mathrm{IU} / \mathrm{ml}$ penicillin, $100 \mu \mathrm{g} / \mathrm{ml}$ streptomycin, and $2 \mathrm{mM}$ L-Glutamine). After 10 to 14 days in culture, microglia were isolated from the mixed glial cultures by the shake-off procedure [33]. Loosely adherent microglia were shaken off at $250 \mathrm{rpm}$ for $2 \mathrm{hr}$ at $37^{\circ} \mathrm{C}$. The cell-containing medium was centrifuged at $180 \times g$ for $3 \mathrm{~min}$, and the cells were seeded onto 48 -well plate at a density of $2 \times 10^{4}$. Alternatively, the mixed glia cultures were trypsinized and seeded onto a 48 -well plate at a density of $2 \times 10^{4}$. Cells were maintained for $24 \mathrm{hr}$ in glia complete medium. LPS (3 $\mathrm{ng} / \mathrm{ml}$ ) or saline veh was then added directly to the glia complete medium for $30 \mathrm{~min}$, after which the LPS- or veh-containing media was removed, the cells were washed once in glia complete medium, and then maintained for $24 \mathrm{hr}$ in glia complete medium. Aliquots $(5 \mu \mathrm{l})$ of the conditioned medium from the primary microglia and the mixed glia cultures were harvested at different times for cytokine measurements.

\section{Peritoneal macrophages and cortical microglia isolation for gene expression}

Peritoneal macrophages were isolated following standard procedures as previously described [34,35]. Briefly, the mice were anesthetized, and $10 \mathrm{ml}$ of PBS was injected into and recollected from the peritoneal cavity. The mice were then transcardiac-perfused with ice-cold PBS. The brain was harvested and the cortex was collected for microglia isolation. Microglia were isolated from the brain using a Percoll gradient following standard procedures as previously described [36]. Briefly, the brain tissue was homogenized in $6.5 \mathrm{ml}$ of ice-cold PBS using a dounce homogenizer. The brain homogenate was added to $3 \mathrm{ml}$ of $100 \%$ isotonic Percoll (ISP) in a $15-\mathrm{ml}$ conical tube and mixed by inversion. A 2-ml layer of 50\% ISP and $2-\mathrm{ml}$ layer of $70 \%$ ISP were layered under the $100 \%$ ISP/brain homogenate (30\% ISP in solution). The $15-\mathrm{ml}$ conical tube containing the Percoll gradient was centrifuged at $500 \times g$ for $20 \mathrm{~min}$ at room temperature. Microglia were collected at the $70 \%$ to $50 \%$ ISP interface. Peritoneal macrophages and cortical microglia were washed once in PBS before RNA extraction. RNA was isolated using an RNeasy kit (Qiagen, Valencia, CA, USA) according to the manufacturer's protocols. RNA quantity and quality were determined using A260/A280 readings by NanoDrop (Thermo Scientific). Reverse transcription (RT) was done following the manufacturer's protocol using a High Capacity cDNA Reverse Transcription Kit (Applied Biosystems, Life Technologies, Grand Island, NY, USA). Controls included no template and no RT conditions. Real-time PCR was performed using the TaqMan Gene Expression Assay kit (Applied Biosystems, Life Technologies, Grand Island, NY, USA) according to the manufacturer's instructions on a ViiA $^{\mathrm{Tm}} 7$ Real-Time PCR System (Applied Biosystems, Life Technologies, Grand Island, NY, USA). The following TaqMan probes (Applied Biosystems) were used: CCR2 (Mm00438270-m1); CX3CR1 (Mm02620111_s1); MAPK14 (Mm00442497_m1); 18S (Hs99999901_s1). Relative gene expression was calculated by the $2-{ }^{\Delta \Delta \overline{C T}}$ method.

\section{Cytokine measurements}

IL-1ra levels were measured with an R\&D Systems DuoSet ELISA kit (R\&D Systems, Minneapolis, MN, USA: cat. no. DY480) according to the manufacturer's specifications. All other cytokine levels were measured as previously described [27,37] using Meso Scale Discovery (MSD: Rockville, MD, USA) custom multiplex high-sensitivity ELISA kits according to the manufacturer's instructions. Tissue cytokine levels were normalized to the total amount of protein in the sample, as determined by BCA Protein Assay (Pierce, Rockford, IL, USA). 


\section{Statistics}

Statistical analysis was conducted using GraphPad prism software V.6 (GraphPad Software, La Jolla, CA, USA: http://www.graphpad.com). Comparisons between LPSstimulated WT and $\mathrm{p} 38 \alpha^{\Delta \text { LysM-Cre }} \mathrm{KO}$ mice were made by unpaired t-test. Comparisons were not made between naïve, or vehicle-injected mice as the cytokine levels were found to be consistently below or at the limit of detection. Statistical significance was defined as $P<0.05$. Values are expressed as mean \pm SEM.

\section{Results}

The in vitro levels of TNFa in response to lipopolysaccharide are reduced in the $\mathrm{p} 38 a^{\Delta \text { LysM-Cre }}$ knockout mice

We have previously demonstrated using primary microglia cultures that the induction of TNF $\alpha$ in response to TLR activation is governed by $\mathrm{p} 38 \alpha$, such that loss or inhibition of $\mathrm{p} 38 \alpha$ results in less TNF $\alpha$ in response to stimuli $[27,32]$. However, in vivo, we recently found that the role of $\mathrm{p} 38 \alpha$ in regulating proinflammatory cytokine responses, including $\mathrm{TNF} \alpha$, is more complicated than that predicted from our in vitro results. Specifically, using a LysM-Cre mouse line to selectively knock out p38 $\alpha$ in cells of the myeloid lineage $\left(\mathrm{p} 38 \alpha^{\Delta \text { LysM-Cre }} \mathrm{KO}\right.$ mice), we found that the acute (6 hr post-injury) proinflammatory cytokine response to a diffuse TBI was enhanced in the $\mathrm{KO}$ mice compared to WT controls, even though the chronic cytokine levels were reduced in the p38 $\alpha^{\Delta \text { LysM-Cre }}$ KO mice [28]. These in vivo results suggest that $\mathrm{p} 38 \alpha$ can both stimulate and unexpectedly limit the CNS proinflammatory cytokine response to injury. However, the mechanism by which $\mathrm{p} 38 \alpha$ may suppress the acute CNS proinflammatory cytokine response has yet to be identified.

To begin to elucidate the mechanism by which $\mathrm{p} 38 \alpha$ could limit the CNS proinflammatory cytokine response, we returned to our in vitro primary microglia and mixed glia assays. Our prior work measured the levels of TNF $\alpha$ that accumulated in the conditioned media with LPS present in cultures for a minimum of $18 \mathrm{hr}$. However, our in vivo TBI results showed that the acute cytokine response was higher in the $\mathrm{p} 38 \alpha^{\Delta \text { LysM-Cre }} \mathrm{KO}$ mice at $6 \mathrm{hr}$ post-injury, but lower by $7 \mathrm{~d}$ post-injury [28]. We hypothesized that p38 $\alpha$ may have different effects temporally in the TNF $\alpha$ response (that is, an acute spike during the first $6 \mathrm{hr}$ in TNF $\alpha$ levels), which we did not detect in our prior in vitro assays when LPS was continuously present, and TNF $\alpha$ was allowed to accumulate in the well for $18 \mathrm{hr}$. To test this idea, we treated primary microglia cultures with LPS for only $30 \mathrm{~min}$, then removed the media, washed the cells once, and then added fresh medium (without LPS). The purpose of removing the LPS was to eliminate the chronic TLR4 pathway activation, which we know in microglia is partially dependent on $\mathrm{p} 38 \alpha[27,32]$; in this way we could look more selectively at feedback mechanism. We sampled $5 \mu \mathrm{l}$ of microglia-conditioned media every $2 \mathrm{hr}$ for the first $8 \mathrm{hr}$ and at $24 \mathrm{hr}$ after LPS stimulation, and measured TNF $\alpha$ levels. As shown in Figure 1A, at all time points from 2 to

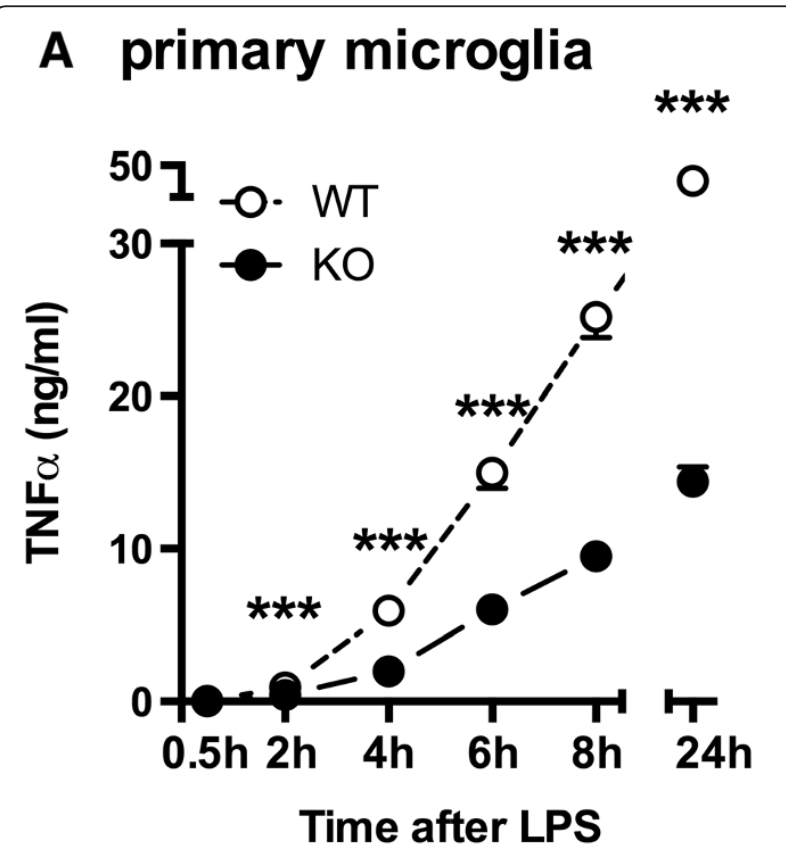

\section{B mixed glia}

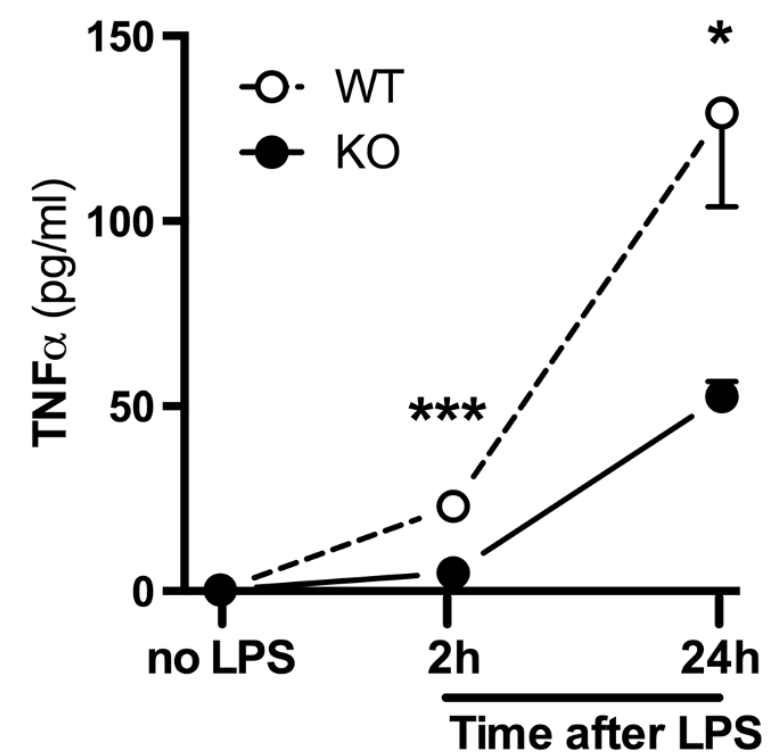

Figure 1 Microglia and mixed glia cultures from $p 38 a^{\Delta L y s M-C r e}$ knockout (KO) are less responsive to lipopolysaccharide (LPS). Wild-type (WT) (white) or p38a $a^{\Delta \text { LysM-Cre }} \mathrm{KO}$ (black) primary microglia (A) and mixed glia (B) were stimulated with LPS for 30 min, cells washed, and then conditioned media was harvested at select time points for TNFa Meso Scale Discovery (MSD) assays. The data are representative of three independent experiments. $\left({ }^{*} P<0.05 ;{ }^{* *} P<0.0005\right)$. 
$24 \mathrm{hr}$, significantly lower TNF $\alpha$ levels were found in the

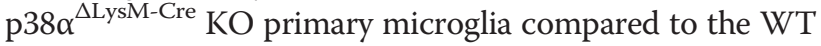
microglia $\left({ }^{* * *} P<0.0005\right)$, in agreement with our prior work $[27,32]$.

The primary microglia assays we use are enriched such that approximately $95 \%$ of the cells are microglia. Therefore, we postulated that an interaction between astrocytes and microglia might account for the in vivo findings, which would not be observed when microglia were in isolation from astrocytes. To test this potential mechanism, we measured the production of TNF $\alpha$ in mixed glia cultures (astrocytes and microglia) treated with LPS and found that the levels of TNF $\alpha$ were also significantly lower in the mixed glia from $\mathrm{p} 38 \alpha^{\Delta \mathrm{LysM}-\mathrm{Cre}}$ KO mice compared to the WT mice (Figure 1B). Thus, primary microglia or mixed glia cultures derived from p38 $\alpha^{\Delta \text { LysM-Cre }}$ KO mice show significantly less TNF $\alpha$ induction in response to LPS stimulation compared to WT mice at all time points examined from 2 to $24 \mathrm{hr}$. Overall, these results do not explain the in vivo observation of enhanced acute proinflammatory cytokine response following TBI in p38 $\alpha^{\Delta \text { LysM-Cre }} \mathrm{KO}$ mice.

\section{In vivo, p38a is efficiently deleted in acutely isolated adult peritoneal macrophages, but not in acutely isolated microglia from $\mathrm{p} 38 \mathrm{a}^{\Delta \text { LysM-Cre }}$ knockout mice}

Recently, Butovsky et al. (2014) reported the gene expression signature of acutely isolated lymphocytes ( $\mathrm{B}$ and $\mathrm{T}$ cells), myeloid cells (that is, dendritic cells, macrophages, and microglia), as well as astrocytes, oligodendrocytes, and neurons [38]. Microglia were found to express 10 times higher levels of p38 $\alpha$ (MAPK14) compared to astrocytes, oligodendrocytes, or neurons. In addition, microglia expressed two- to threefold more p $38 \alpha$ than other tissue macrophage populations [38]. We previously reported [27,32] that p38 $\alpha$ is efficiently depleted in primary microglia from p38 $\alpha^{\text {LysM-Cre }}$ KO mice. However, the LysM-Cre mouse line may not have equal efficiency at knocking down p38 $\alpha$ in vivo in all myeloid cell populations. For example, the recombination efficacy of the LysM-Cre in microglia in the adult brain has been shown to be between 20 and $45 \%$, depending on the brain region and the method used to assess the recombination [39]. Since both the relative expression of $p 38 \alpha$ and the efficiency of the LysM-Cre promoter can vary in different myeloid cell populations, we measured the level of $\mathrm{p} 38 \alpha$ suppression in acutely isolated peritoneal macrophages and cortical microglia from WT and p38 $\alpha^{\Delta \text { LysM-Cre }}$ KO mice.

Using CCR2 and CX3CR1 as markers for macrophages and microglia, respectively, we found high levels of CCR2 in the peritoneal macrophages, and high levels of CX3CR1 in the microglia cell fraction (Figure 2), consistent with previous studies [40]. The gene expression of CCR2 and CX3CR1 indicated that our isolation resulted in enrichment of the target cell populations. In the WT mice, we confirmed that expression of $\mathrm{p} 38 \alpha$ was higher in the microglia fraction compared to the macrophage population (Figure 2), as previously reported [38]. Interestingly, in the $\mathrm{p} 38 \alpha^{\Delta \text { LysM-Cre }} \mathrm{KO}$ mice, macrophages but not microglia were found to have efficient deletion of $\mathrm{p} 38 \alpha$ (Figure 2). It should be noted that CCR2 and CX3CR1 expression alone does not indicate whether cells other than macrophages or microglia are present in our cell fractions; therefore these results may underestimate the percentage of microglia that may be p38 $\alpha$ deficient.

These findings would appear to be in disagreement with our previous reports that $\mathrm{p} 38 \alpha$ is efficiently depleted in primary microglia from $\mathrm{p} 38 \alpha^{\Delta \text { LysM-Cre }} \mathrm{KO}$ mice $[27,32]$. One potential explanation for the discrepancy is the culture conditions, as primary microglia are activated by removal from the CNS tissue environment. The in vitro activation associated with the primary culture could be sufficient to increase the expression of LysM, and the 10 to $14 \mathrm{~d}$ of culture would be enough time for the Cre/loxP recombination to result in a loss of $\mathrm{p} 38 \alpha$. Therefore, microglia in culture appear to be more similar to peritoneal macrophages than to acutely isolated microglia from adult mice in terms of efficiency of p38 $\alpha$ knockdown.

\section{The proinflammatory cytokine response to intracerebroventricular (ICV) injection of LPS is not suppressed in the $\mathrm{p} 38 a^{\Delta \mathrm{LysM}-\mathrm{Cre}} \mathrm{KO}$ mice}

We next postulated that the difference in the acute proinflammatory cytokine response between our in vivo diffuse TBI model and our in vitro LPS model could be the result of different stressor stimuli. To test this idea, we induced a sterile inflammatory response in the CNS by the injection of $25 \mathrm{ng}$ of LPS into the right lateral ventricle of WT mice and $\mathrm{p} 38 \alpha^{\Delta \mathrm{LysM}-\mathrm{Cre}} \mathrm{KO}$ mice, thus mirroring our in vitro LPS assays. Mice were euthanized at $6 \mathrm{hr}$ post-injection, which was determined by a preliminary experiment (data not shown) as the peak of the IL-1 $\beta$ response in the ipsilateral hippocampus following ICV LPS. Figure 3A shows that levels of three proinflammatory cytokines (IL-1 $\beta$, IL-6, and TNF $\alpha$ ) were increased in the hippocampus at $6 \mathrm{hr}$ after ICV LPS administration. IL-1 $\beta$ and TNF $\alpha$ showed no difference between the LPSstimulated WT and $\mathrm{p} 38 \alpha^{\Delta \text { LysM-Cre }} \mathrm{KO}$ mice. The only difference between LPS-stimulated WT and p38 $\alpha^{\text {LysM-Cre }}$ $\mathrm{KO}$ mice in CNS responses was a significantly higher upregulation of IL-6 $\left(\mathrm{t}_{(14)}=2.246 \mathrm{p}=0.014\right)$ in the cortex, as well as in the serum of $\mathrm{p} 38 \alpha^{\Delta \mathrm{LysM}-\mathrm{Cre}} \mathrm{KO}$ mice compared to WT mice (Figure 3B: $\left(\mathrm{t}_{(14)}=3.635 \mathrm{p}=0.0027\right)$ ). We replicated this experiment twice with $100 \mathrm{ng}$ and $1 \mu \mathrm{g}$ of LPS and found no difference in IL-1 $\beta$ levels between 


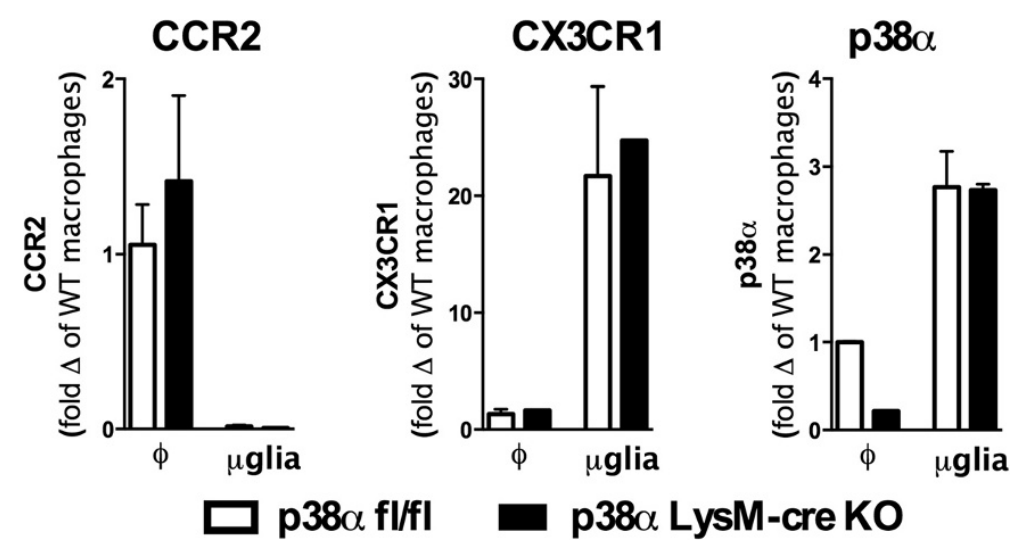

Figure 2 Isolation of peritoneal macrophages $(\varphi)$ and microglia ( $\mu$ glia) from adult mice shows enrichment of CCR2 and CX3CR1 cell populations, and loss of $\mathbf{p} 38 \mathrm{a}$ in the isolated macrophages but not in the microglia fraction. RNA was extracted from peritoneal macrophages or microglia isolated from cortical tissue using a discontinuous Percoll gradient. qRT-PCR using TaqMAN Gene Expression Assays was used to determine CCR2, CX3CR1, and p38a (MAPK14) expression in the isolated cell populations. Data are presented as fold change of wild-type (WT) macrophages. The data are representative of two independent experiments.

p38 $\alpha^{\Delta \text { LysM-Cre }}$ KO mice compared to WT mice at $6 \mathrm{hr}$ post-injection (data not shown), indicating that the LPS dose was not a critical variable. We previously found that IL-1 $\beta$, IL-6 and TNF $\alpha$ were increased both at the protein and mRNA level in the cortex following a diffuse TBI in p38 $\alpha^{\Delta \text { LysM-Cre }}$ KO mice [28]. Therefore, the ICV LPS model more closely resembled our in vivo diffuse TBI model, than our in vitro LPS model. However, the ICV LPS model did not mirror the overproduction of IL- $1 \beta$ and TNF $\alpha$ seen in the in vivo diffuse TBI model. Nevertheless, the ICV LPS model did not show a reduced proinflammatory cytokine response in the $\mathrm{p} 38 \alpha^{\text {LysM-Cre }} \mathrm{KO}$ mice, as seen in the in vitro LPS model. A difference in the stressor stimuli is thus not able to explain the acutely elevated levels of proinflammatory cytokines in the CNS following diffuse TBI in $\mathrm{p} 38 \alpha^{\Delta \text { LysM-Cre }} \mathrm{KO}$ mice [28]. As microglia in the $\mathrm{p} 38 \alpha^{\Delta \mathrm{LysM}-\mathrm{Cre}} \mathrm{KO}$ mice are not $\mathrm{p} 38 \alpha$ deficient in vivo, the overproduction of IL-6 in response to ICV LPS may come from systemic cells, or circulating factors.

The CNS proinflammatory cytokine response to systemic lipopolysaccharide is enhanced, while the systemic proinflammatory response is suppressed in the p38 $a^{\text {LLsM-Cre }}$ knockout mice

To test the hypothesis that an altered systemic inflammatory response may account for the increased proinflammatory cytokine response in the CNS following diffuse TBI in $\mathrm{p} 38 \alpha^{\Delta \mathrm{LysM}-\mathrm{Cre}} \mathrm{KO}$ mice, we used an intraperitoneal (IP) LPS model. WT and p38 $\alpha^{\Delta \text { LysM-Cre }} \mathrm{KO}$ mice were injected IP with $5 \mathrm{mg} / \mathrm{kg}$ LPS $\left(3 \times 10^{6} \mathrm{EU} /\right.$ $\mathrm{mg}$ ). Additionally, to further explore differences in the temporal patterning of the proinflammatory cytokine response in the WT and p38 $\alpha^{\Delta \text { LysM-Cre }}$ KO mice, serum and cortical tissue were harvested at different time points after
LPS insult. In agreement with previous studies [29], we found a significantly lower serum cytokine response to LPS in the $\mathrm{p} 38 \alpha^{\Delta \text { LysM-Cre }} \mathrm{KO}$ mice compared to WT mice (Figure $4 \mathrm{~A}$ ). At 1 hr post-injection, the $\mathrm{p} 38 \alpha^{\Delta \mathrm{LysM}-}$ Cre KO mice had significantly less IL-6 $\left(\mathrm{t}_{(8)}=5.062 P=\right.$ $0.001)$ and TNF $\alpha\left(t_{(8)}=2.479 P=0.0382\right)$ compared to the WT mice. In agreement with our previous study in the diffuse TBI model [28], we found a significantly elevated peak LPS-induced CNS cytokine response in the p38 $\alpha^{\Delta \text { LysM-Cre }}$ KO mice compared to the WT mice (Figure 4B). At $6 \mathrm{hr}$ post-injection, levels of IL-1 $\beta\left(\mathrm{t}_{(16)}=\right.$ $3.823 P=0.0015)$, IL-6 $\left(\mathrm{t}_{(7)}=3.526 P=0.0097\right)$, and TNF $\alpha$ $\left(\mathrm{t}_{(16)}=2.328 P=0.0333\right)$ were significantly higher in the p38 $\alpha^{\Delta \text { LysM-Cre }} \mathrm{KO}$ compared to the WT mice. In an independent experiment, we used a lower dose of LPS (1 mg/ $\mathrm{kg}$ ) and still found a significant increase in IL-1 $\beta$ and IL-6 in the CNS of $\mathrm{p} 38 \alpha^{\Delta \mathrm{LysM}-\mathrm{Cre}} \mathrm{KO}$ mice compared to the WT mice at $6 \mathrm{hr}$ post injection (data not shown). Therefore, the results of the IP LPS model support the hypothesis that systemic cells, or circulating factors dependent on $\mathrm{p} 38 \alpha$, are important for limiting the proinflammatory cytokine response in the CNS.

The $\mathrm{p} 38 a^{\Delta \text { LysM-Cre }}$ knockout mice fail to produce IL-10 in response to systemic lipopolysaccharide

It has been previously reported that $\mathrm{p} 38 \alpha$ is involved in the production of two anti-inflammatory cytokines, IL-1ra [41] and IL-10 [42,43]. Therefore, we hypothesized that loss of a paracrine anti-inflammatory response might be responsible for the increased CNS proinflammatory cytokines in the $\mathrm{p} 38 \alpha^{\Delta \mathrm{LysM}-\mathrm{Cre}} \mathrm{KO}$ mice. To test this, we measured serum and cortex levels of IL-1ra and IL-10 after systemic LPS administration to WT and $\mathrm{p} 38 \alpha^{\Delta \text { LysM-Cre }} \mathrm{KO}$ mice. We found no significant difference in the levels of IL-1ra in the serum between WT and $\mathrm{p} 38 \alpha^{\Delta \text { LysM-Cre }} \mathrm{KO}$ 


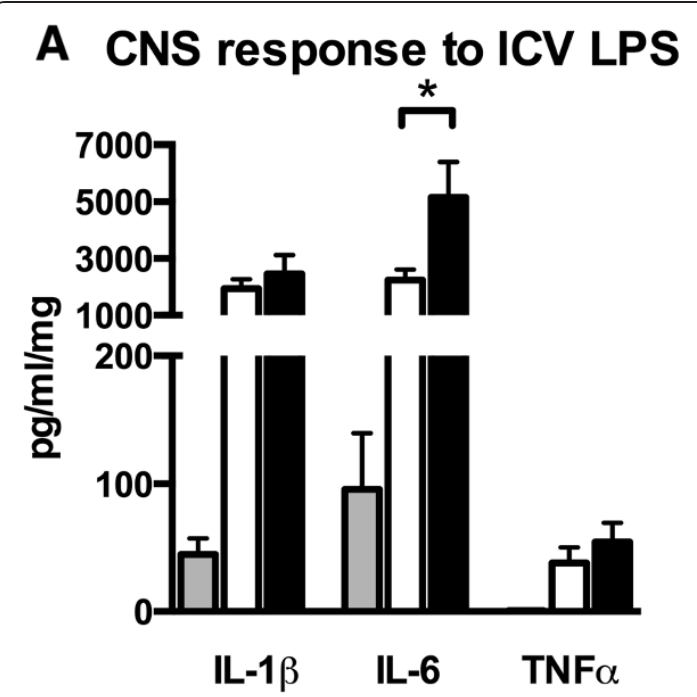

\section{B serum response to ICV LPS}

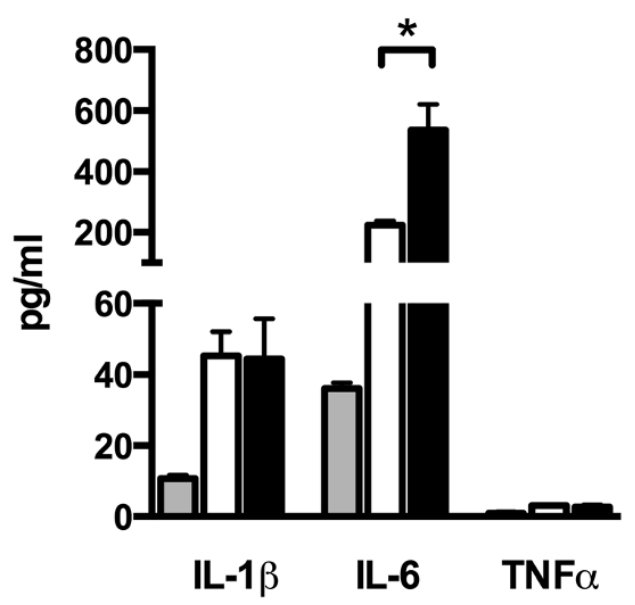

\section{$\square$ veh $\square$ WT + LPS $\quad$ KO + LPS}

Figure 3 p38 $a^{\Delta \text { LysM-Cre }}$ knockout (KO) mice show no suppression of the proinflammatory cytokine response to intracerebroventricular (ICV) injection of lipopolysaccharide (LPS). At $6 \mathrm{hr}$ post-ICV injection, levels of cytokines were measured in the ipsilateral hippocampus (A) and serum (B) of wild-type (WT) mice (white) or $\mathrm{p} 38 \mathrm{a}^{\mathrm{\Delta LySM}-\mathrm{Cre}} \mathrm{KO}$ mice administered saline (vehicle (veh): gray) or $25 \mathrm{ng}$ LPS (black). ( $\mathrm{n}=4$ per veh group (WT $=2$, $\mathrm{KO}=2) ; \mathrm{n}=8$ per LPS group) $\left({ }^{*} P<0.05\right)$.

mice at any time point measured (Figure 5A). In contrast, we found that the levels of IL-10 in the serum were markedly suppressed in the $\mathrm{p} 38 \alpha^{\mathrm{LLysM}-C r e} \mathrm{KO}$ mice compared to the WT mice following LPS stimulation (Figure 5A). At $1 \mathrm{hr}$, a highly significant $\left(\mathrm{t}_{(8)}=6.033 P=0.0003\right)$ suppression of the IL-10 response was seen in the p38 $\alpha \mathrm{KO}$ mice. The levels of IL-10 in the serum of the $\mathrm{p} 38 \alpha^{\Delta \mathrm{LysM}-\mathrm{Cre}} \mathrm{KO}$ mice remained suppressed at the $6 \mathrm{hr}\left(\mathrm{t}_{(8)}=4.996 \mathrm{P}=\right.$ $0.0011)$ and $24 \mathrm{hr}\left(\mathrm{t}_{(8)}=3.727 P=0.0058\right)$ time points compared to the WT mice. In the cortex, there was also no significant difference in the levels of IL-1ra (Figure 5B) between $\mathrm{p} 38 \alpha^{\text {LysM-Cre }} \mathrm{KO}$ and WT mice. At $6 \mathrm{hr}$ after LPS, there were lower IL-10 levels in the cortex of p38 $\alpha^{\Delta \text { LysM-Cre }}$ KO mice compared to the WT mice, but the decrease did not reach significance (Figure $5 \mathrm{~B}$ ). Thus, a loss of the systemic IL-10 response in the p $38 \alpha^{\Delta \text { LysM-Cre }}$ $\mathrm{KO}$ could be the mechanism by which proinflammatory cytokine response in the CNS becomes exaggerated.

\section{Discussion}

The goal of this project was to explore the potential mechanism by which $\mathrm{p} 38 \alpha$ could suppress the acute proinflammatory cytokine response in the CNS. Our prior work, using in vitro assays, demonstrated that p38 $\alpha$ is critical for the production of IL- $1 \beta$ and TNF $\alpha$ from activated microglia [27,32]. We also previously showed, using a small molecule p38 $\alpha$ inhibitor, that suppression of the p38 signal transduction pathway limits the IL- $1 \beta$ response in the CNS to systemic LPS $[17,27,44]$. Moreover, we found that $\mathrm{p} 38 \beta$ MAPK is not involved in the CNS cytokine production, or in neurotoxicity induced by LPS inflammatory insult or multiple toxic insults $[45,46]$. Despite this strong precedent for $\mathrm{p} 38 \alpha$, we recently found that in a diffuse TBI model the acute proinflammatory cytokine response in the CNS was higher in the $\mathrm{p} 38 \alpha^{\text {LlysM-Cre }} \mathrm{KO}$ mice [28]. Therefore, we sought to determine the mechanism by which $\mathrm{p} 38 \alpha$ could limit the acute proinflammatory response, as this could be critical in the use of p38 $\alpha$ as a therapeutic target to treat diseases of the CNS that have inflammation as one component of the pathophysiology.

Collectively, our results suggest that $\mathrm{p} 38 \alpha$ has a critical role in limiting the acute cytokine storm, and the spread of the systemic innate immune response to the CNS, by regulating the production of the anti-inflammatory cytokine IL-10. A peripheral injection of LPS into the peritoneal cavity initiates a systemic innate immune response. There remains a debate of how the peripheral inflammation leads to a neuroinflammatory response. However, acute phase proteins (that is, prostaglandin E2), cytokines (that is, IL-1 $\beta$ ) and LPS itself have been suggested to be involved in the mechanism by which a peripheral LPS stimulation induces neuroinflammation [47-51]. In agreement with previous studies [29], we found that levels of the proinflammatory cytokines IL-1 $\beta$, IL-6, and TNF $\alpha$ were all decreased in the serum of mice where macrophages were deficient in $\mathrm{p} 38 \alpha$. Despite the decrease in the proinflammatory cytokine response in the serum, the peak of the proinflammatory response in the CNS was significantly higher in the $\mathrm{p} 38 \alpha^{\Delta \mathrm{LysM}-\mathrm{Cr}} \mathrm{KO}$ mice. Our data are consistent with a model (Figure 6) whereby systemic LPS induces an acute phase response, including upregulation of both pro- and anti-inflammatory cytokines. In WT mice, the balance of the pro- and anti-inflammatory cytokine 


\section{A serum response to IP LPS}
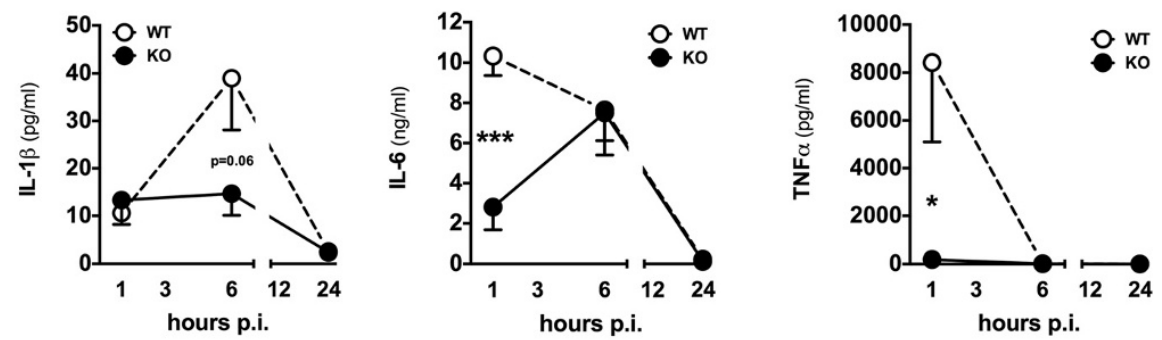

\section{B CNS response to IP LPS}
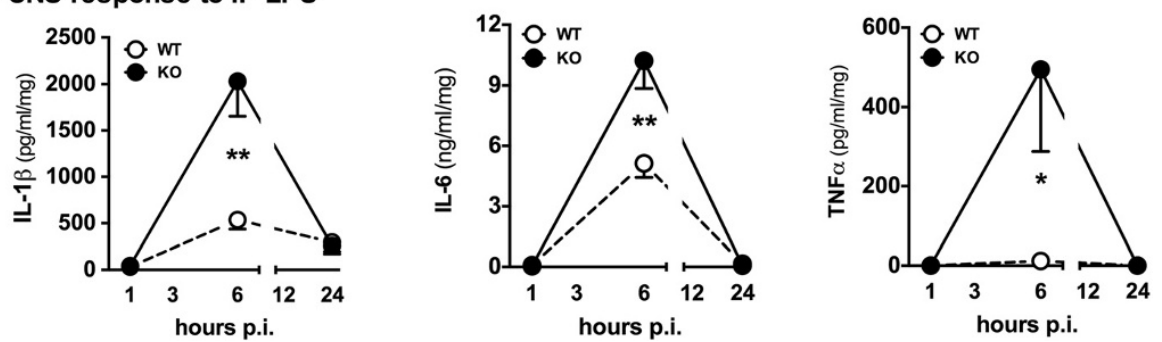

Figure 4 Levels of pro-inflammatory cytokines in the serum and cortex of mice following systemic lipopolysaccharide (LPS) stimulation. Wild-type (WT) mice (white) or p38a ${ }^{\Delta \text { LysM-Cre }}$ knockout (KO) mice (black) were injected intraperitoneally (IP) with $5 \mathrm{mg} / \mathrm{kg}$ LPS. The cytokine response

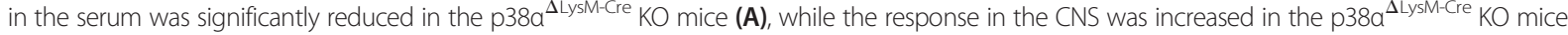
compared to the WT mice (B) $\left(n=5\right.$ to 8 per group) $\left({ }^{*} P<0.05 ;{ }^{* *} P<0.01 ; * * *<0.001\right)$.
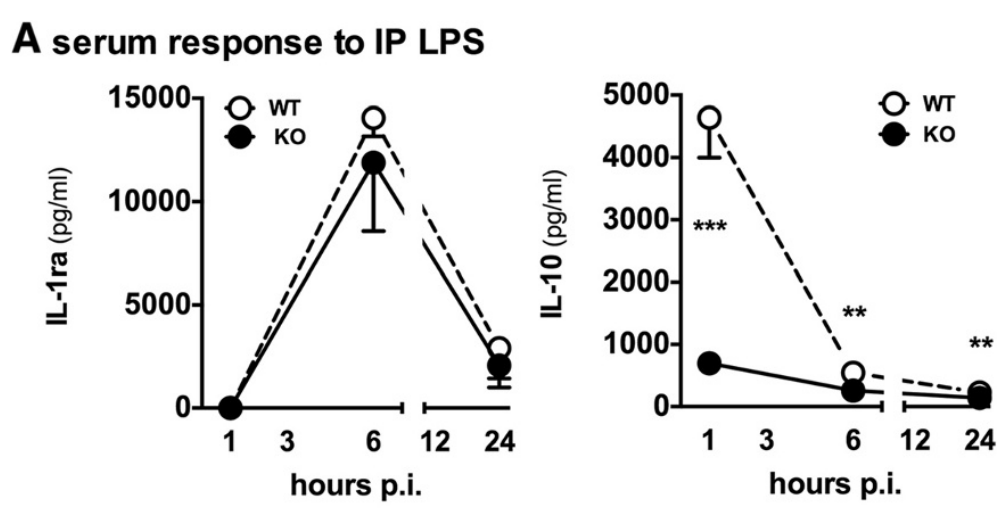

\section{B CNS response to IP LPS}
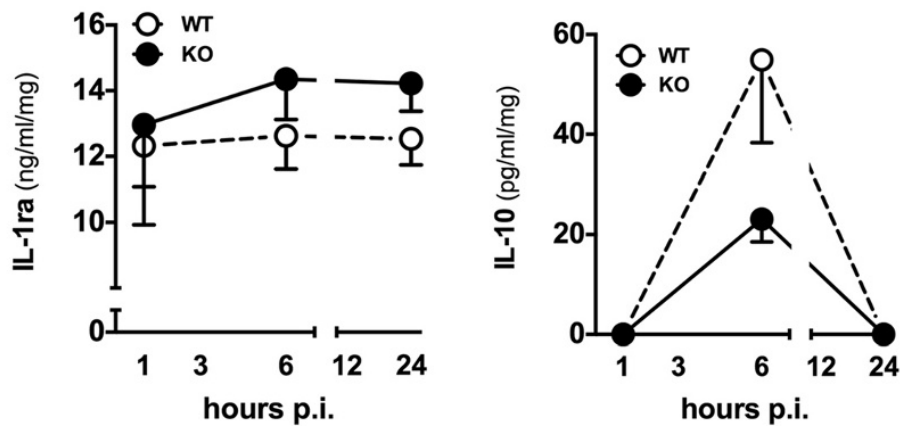

Figure $\mathbf{5}$ Levels of anti-inflammatory cytokines in the serum and cortex of mice following systemic lipopolysaccharide (LPS) stimulation. Wild-type (WT) mice (white) or p38a ${ }^{\text {LysM-Cre }}$ knockout (KO) mice (black) were injected intraperitoneally (IP) with $5 \mathrm{mg} / \mathrm{kg}$ LPS. No significant differences in IL-1 ra levels in serum (A) or CNS (B) were detected between WT and $\mathrm{p38a^{ \Delta LysM-Cre } K O}$ mice. Levels of IL-10 in the serum were significantly reduced in the $\mathrm{p} 38 a^{\Delta L y s M-C r e} \mathrm{KO}$ mice (A), and there was a trend for reduced levels of IL-10 in the CNS (B) although the data did not reach statistical significance ( $n=5$ to 8 per group) $\left({ }^{* *} P<0.01\right.$; $\left.{ }^{* * *} P<0.001\right)$. 


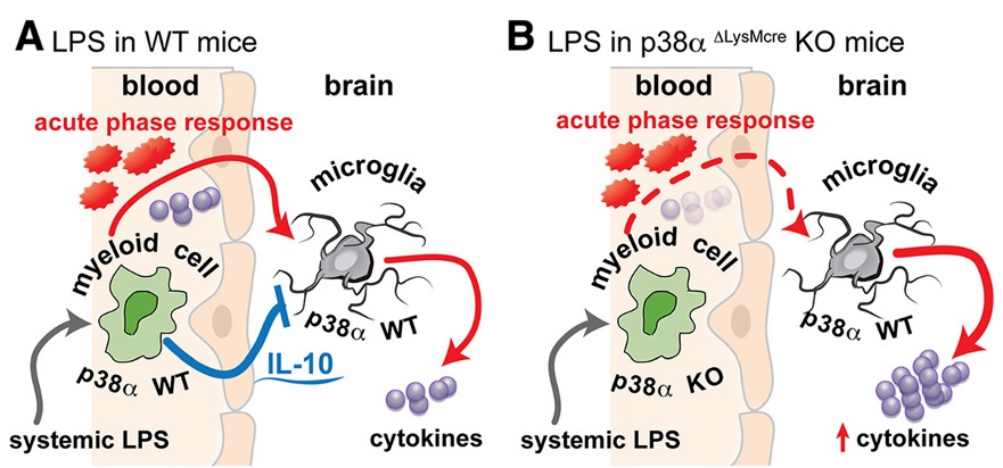

Figure 6 Proposed model for p38a in myeloid cell cytokine response to systemic lipopolysaccharide (LPS). (A) In wild-type (WT) mice, myeloid cells respond to systemic LPS by producing an acute phase response, including the production of proinflammatory cytokines, as well as the anti-inflammatory cytokine IL-10. The systemic response spreads to the brain where microglia produce cytokines locally in the CNS. (B) In the p38a $a^{\Delta \text { Lys M-Cre }}$ knockout $(\mathrm{KO})$ mice, the systemic acute phase response is suppressed such that there is less proinflammatory cytokine production in the blood. However, there is also a loss of the negative feedback provided by the anti-inflammatory IL-10, which we propose leads to an exaggerated acute proinflammatory cytokine response in the CNS.

response, along with other acute phase mechanisms, leads to an increase in cytokines in the CNS (Figure 6A). However, if circulating IL-10 levels are not elevated to counterbalance the increased systemic proinflammatory responses, the spread of the inflammatory response from the periphery to the CNS is exaggerated. This model is also consistent with data from IL-10 deficient mice, in a large number of in vivo inflammatory models, which collectively suggest that no other anti-inflammatory cytokine can compensate for the loss of IL-10, because without IL-10, there will be aberrant proinflammatory cytokine overproduction (for review see: [52]). Our results reported here demonstrate that $\mathrm{p} 38 \alpha$ is required by myeloid cells to produce IL-10 in response to systemic LPS, and without an effective IL-10 response - a defect seen in the $\mathrm{p} 38 \alpha^{\Delta \mathrm{LysM}-\mathrm{Cre}} \mathrm{KO}$ mouse - neuroinflammation can be exaggerated (Figure 6B).

The systemic balance between pro- and anti-inflammatory factors can influence the proinflammatory cytokine response in the CNS. For example, relevant to the current study, IL-10 is able to block proinflammatory cytokine upregulation in the CNS in response to ICV or IP LPS administration [53,54] and to spinal cord injury [55]. Moreover, IP LPS in IL-10 KO mice results in a significantly exaggerated TNF $\alpha$, IL-1 $\beta$ and IL- 6 response in the plasma and in the CNS compared to WT mice [56], following a similar pattern to our results. Both microglia and astrocytes express the IL-10 receptor; however, in vitro IL-10 was found to have a suppressive effect only on astrocytes and not microglia [57]. The effect of IL-10 on microglia was found to be indirect through the astrocyte production of TGF $\beta$ [57]. We do not know if this mechanism would also be true in our model, but understanding the crosstalk between microglia and astrocytes in regulating the balance between pro- and anti-inflammatory factors is an important future direction.
The broad anti-inflammatory properties of IL-10 are a result of IL-10's ability to inhibit innate function of macrophages, neutrophils, and dendritic cells including their production of proinflammatory cytokines $[52,58]$. The present study confirmed previous observations [43,59] that macrophages require p38 $\alpha$ for the production of IL-10, which suggests that the induction of this anti-inflammatory cytokine may limit the CNS inflammatory response to LPS. This finding is in agreement with the role of mitogen-andstress-activated kinases 1 and 2 (MSK1/2) in the production of IL-10 [42,43]. MSK1/2 is activated by p38 and Erk1/2 [60]. Microglia and macrophages deficient in p38 $\alpha$ have been shown to have decreased levels of the activated phospho-MSK1/2 [27,42,43]. Critically, MSK1/2 double $\mathrm{KO}$ mice are found to have elevated proinflammatory cytokine responses to LPS, which is IL-10 dependent, as illustrated elegantly by the use of an MSK1/2 / IL-10 triple KO mouse [42]. In addition to the MSK1/2 pathway, p38 $\alpha$ can also regulate IL-10 expression in macrophages via the direct downstream target of p38 $\alpha$, the MAPK-activated protein kinase 2 [61]. Defining why Erk $1 / 2$ is not able to compensate for the loss of $\mathrm{p} 38 \alpha$ will require future studies to understand potential crosstalk between $\mathrm{p} 38 \alpha$ and Erk1/2 in regulating IL-10 levels following in vivo LPS stimulation.

\section{Conclusions}

We and others have previously reported using small molecule inhibitors that suppression of $\mathrm{p} 38 \alpha$ can reduce neuroinflammation in vivo $[16,17,19,23,27]$. In the current study, we found that the peak proinflammatory cytokine response to systemic LPS in vivo is significantly greater in the CNS of $\mathrm{p} 38 \alpha^{\Delta \mathrm{LysM}-\mathrm{Cre}} \mathrm{KO}$ mice compared to the WT mice, replicating the result found in a diffuse TBI model [28]. We also found that after systemic stimulation of the 
innate immune system with LPS, $\mathrm{p} 38 \alpha$ was necessary for a stimulus-induced increase in serum levels of the antiinflammatory cytokine IL-10. Therefore, p38 $\alpha$ appears to be a fulcrum in balancing the systemic innate immune response, by regulating levels of pro- and anti-inflammatory cytokines. While p38 $\alpha$ appears to be a promising therapeutic target, our work here highlights the complexity of such efforts. The observations that $\mathrm{p} 38 \alpha$ may balance the inflammatory response by acutely attenuating the early proinflammatory cytokine surge, while perpetuating the chronic microglia activation response raise the importance of considerations of an optimal therapeutic window for the efficacy of p38 $\alpha$ inhibitors. Our findings that p38 $\alpha$ dependent systemic inflammatory responses affect the CNS inflammatory responses also suggest that measurement of systemic IL-10 and TNFa levels in serum or plasma might be a useful tool for monitoring the anti- and pro-inflammatory cytokine balance during the course of treatment of CNS disorders.

\section{Abbreviations}

AD: Alzheimer's disease; CNS: central nervous system; ICV: intracerebroventricular; IP: intraperitoneal; IL-1: interleukin-1; IL-1 ra: IL-1 receptor antagonist; ISP: isotonic Percoll; KO: knockout; LPS: lipopolysaccharide; MAPK: mitogen-activated protein kinase; MSD: Meso Scale Discovery; MSK1/2: mitogen-and-stress-activated kinases 1 and 2; RT: reverse transcription; TLR: toll-like receptor; TNFa: tumor necrosis factor alpha; veh: vehicle; WT: wild type.

\section{Competing interests}

The authors declare that they have no competing interests.

\section{Authors' contributions}

$A D B$ and LVE designed the research studies. ADB and BX performed the experiments. ADB and LVE drafted the manuscript with the assistance of the other authors. All authors read and approved the final manuscript.

\section{Acknowledgements}

We thank Edgardo Dimayuga and Danielle Goulding for their assistance with various aspects of this work. This research was supported in part by an Alzheimer's Association Zenith award ZEN-09-134506 (LVE) and NIH grants R01 NS064247 (LVE), F32 AG037280 (ADB), and K99 AG044445 (ADB). We are grateful to Dr. Huiping Jiang at Boehringer Ingelheim Pharmaceuticals, Inc. and Dr. Jiahuai Han at The Scripps Research Institute for the kind gifts of the knockout mice.

\section{Author details}

${ }^{1}$ Sanders-Brown Center on Aging, University of Kentucky, 800 S. Limestone Street, Lexington, KY 40536, USA. ²Department of Anatomy and Neurobiology, University of Kentucky, 800 S. Limestone Street, Lexington, KY 40536, USA. ${ }^{3}$ Current Affiliation: VA Pittsburgh Healthcare System, 3501 Fifth Avenue, Pittsburgh, PA 15260, USA

Received: 24 August 2014 Accepted: 29 September 2014 Published online: 10 October 2014

\section{References}

1. Mrak RE, Griffin WST: Glia and their cytokines in progression of neurodegeneration. Neurobiol Aging 2005, 26:349-354.

2. Glass CK, Saijo K, Winner B, Marchetto MC, Gage FH: Mechanisms underlying inflammation in neurodegeneration. Cell 2010, 140:918-934.

3. Wyss-Coray T, Rogers J: Inflammation in Alzheimer disease-a brief review of the basic science and clinical literature. Cold Spring Harb Perspect Med 2012, 2:a006346.
4. Tansey MG, Goldberg MS: Neuroinflammation in Parkinson's disease: its role in neuronal death and implications for therapeutic intervention. Neurobiol Dis 2010, 37:510-518.

5. Das M, Mohapatra S, Mohapatra SS: New perspectives on central and peripheral immune responses to acute traumatic brain injury. J Neuroinflammation 2012, 9:236.

6. David S, Kroner A: Repertoire of microglial and macrophage responses after spinal cord injury. Nat Rev Neurosci 2011, 12:388-399.

7. ladecola C, Anrather J: The immunology of stroke: from mechanisms to translation. Nat Med 2011, 17:796-808.

8. Van Eldik LJ, Thompson WL, Ralay Ranaivo H, Behanna HA, Martin Watterson D: Glia proinflammatory cytokine upregulation as a therapeutic target for neurodegenerative diseases: function-based and target-based discovery approaches. Int Rev Neurobiol 2007, 82:277-296.

9. McCoy MK, Tansey MG: TNF signaling inhibition in the CNS: implications for normal brain function and neurodegenerative disease. J Neuroinflammation 2008, 5:45

10. Li Y, Liu L, Barger SW, Griffin WS: Interleukin-1 mediates pathological effects of microglia on tau phosphorylation and on synaptophysin synthesis in cortical neurons through a p38-MAPK pathway. J Neurosci 2003, 23:1605-1611.

11. Sheng JG, Jones RA, Zhou XQ, McGinness JM, Van Eldik L, Mrak RE, Griffin WS: Interleukin-1 promotion of MAPK-p38 overexpression in experimental animals and in Alzheimer's disease: potential significance for tau protein phosphorylation. Neurochem Int 2001, 39:341-348.

12. Bachstetter $A D$, Van Eldik LJ: The p38 MAP kinase family as regulators of proinflammatory cytokine production in degenerative diseases of the CNS. Aging Dis 2010, 1:199-211.

13. Lee JC, Laydon JT, McDonnell PC, Gallagher TF, Kumar S, Green D, McNulty D, Blumenthal MJ, Heys JR, Landvatter SW, Strickler JE, Mclaughlin MM, Siemens IR, Fisher SM, Livi GP, White JR, Adams JL, Young PR: A protein kinase involved in the regulation of inflammatory cytokine biosynthesis. Nature 1994, 372:739-746.

14. Margutti S, Laufer SA: Are MAP kinases drug targets? Yes, but difficult ones. Chem Med Chem 2007, 2:1116-1140.

15. Hammaker D, Firestein GS: "Go upstream, young man": lessons learned from the p38 saga. Ann Rheum Dis 2010, 69(Suppl 1):i77-i82.

16. Munoz L, Ranaivo HR, Roy SM, Hu W, Craft JM, McNamara LK, Chico LW, Van Eldik LJ, Watterson DM: Novel p38 alpha MAPK inhibitor suppresses brain proinflammatory cytokine up-regulation and attenuates synaptic dysfunction and behavioral deficits in an Alzheimer's disease mouse model. J Neuroinflammation 2007, 4:21.

17. Watterson DM, Grum-Tokars VL, Roy SM, Schavocky JP, Bradaric BD, Bachstetter AD, Xing B, Dimayuga E, Saeed F, Zhang H, Staniszewski A, Pelletier JC, Minasov G, Anderson WF, Arancio O, Van Eldik U: Development of novel chemical probes to address CNS protein kinase involvement in synaptic dysfunction. PLoS One 2013, 8:e66226.

18. Sugino T, Nozaki K, Takagi $Y$, Hattori I, Hashimoto N, Moriguchi T, Nishida E: Activation of mitogen-activated protein kinases after transient forebrain ischemia in gerbil hippocampus. J Neurosci 2000, 20:4506-4514

19. Piao CS, Kim JB, Han PL, Lee JK: Administration of the p38 MAPK inhibitor SB203580 affords brain protection with a wide therapeutic window against focal ischemic insult. J Neurosci Res 2003, 73:537-544.

20. Legos JJ, Erhardt JA, White RF, Lenhard SC, Chandra S, Parsons AA, Tuma RF, Barone FC: SB 239063, a novel p38 inhibitor, attenuates early neuronal injury following ischemia. Brain Res 2001, 892:70-77.

21. Barone FC, Irving EA, Ray AM, Lee JC, Kassis S, Kumar S, Badger AM, White RF, McVey MJ, Legos JJ, Erhardt JA, Nelson AH, Ohlstein EH, Hunter AJ, Ward K, Smith BR, Adams JL, Parsons AA: SB 239063, a second-generation p38 mitogen-activated protein kinase inhibitor, reduces brain injury and neurological deficits in cerebral focal ischemia. J Pharmacol Exp Ther 2001, 296:312-321.

22. Jin SX, Zhuang ZY, Woolf CJ, Ji RR: p38 mitogen-activated protein kinase is activated after a spinal nerve ligation in spinal cord microglia and dorsal root ganglion neurons and contributes to the generation of neuropathic pain. J Neurosci 2003, 23:4017-4022.

23. Kim SW, Yu YM, Piao CS, Kim JB, Lee JK: Inhibition of delayed induction of p38 mitogen-activated protein kinase attenuates kainic acid-induced neuronal loss in the hippocampus. Brain Res 2004, 1007:188-191. 
24. Fisk M, Gajendragadkar PR, Maki-Petaja KM, Wilkinson IB, Cheriyan J: Therapeutic potential of p38 MAP kinase inhibition in the management of cardiovascular disease. Am J Cardiovasc Drugs 2014, 14:155-165.

25. Huang G, Wang Y, Vogel P, Kanneganti TD, Otsu K, Chi H: Signaling via the kinase p38alpha programs dendritic cells to drive $\mathrm{TH} 17$ differentiation and autoimmune inflammation. Nat Immunol 2012, 13:152-161.

26. Munoz L, Ammit AJ: Targeting p38 MAPK pathway for the treatment of Alzheimer's disease. Neuropharmacology 2010, 58:561-568.

27. Bachstetter AD, Xing B, de Almeida L, Dimayuga ER, Watterson DM, Van Eldik LJ: Microglial p38alpha MAPK is a key regulator of proinflammatory cytokine up-regulation induced by toll-like receptor (TLR) ligands or beta-amyloid (Abeta). J Neuroinflammation 2011, 8:79.

28. Bachstetter AD, Rowe RK, Kaneko M, Goulding D, Lifshitz J, Van Eldik LJ: The p38alpha MAPK regulates microglial responsiveness to diffuse traumatic brain injury. J Neurosci 2013, 33:6143-6153.

29. Kang YJ, Chen J, Otsuka M, Mols J, Ren S, Wang Y, Han J: Macrophage deletion of p38alpha partially impairs lipopolysaccharide-induced cellular activation. J Immuno/ 2008, 180:5075-5082.

30. Clausen BE, Burkhardt C, Reith W, Renkawitz R, Forster I: Conditional gene targeting in macrophages and granulocytes using LysMcre mice. Transgenic Res 1999, 8:265-277.

31. Clarke S, Greaves DR, Chung LP, Tree P, Gordon S: The human lysozyme promoter directs reporter gene expression to activated myelomonocytic cells in transgenic mice. Proc Natl Acad Sci U S A 1996, 93:1434-1438.

32. Xing B, Bachstetter AD, Eldik LJ: Microglial p38alpha MAPK is critical for LPS-induced neuron degeneration, through a mechanism involving TNFalpha. Mol Neurodegener 2011, 6:84.

33. Petrova TV, Akama KT, Van Eldik LJ: Cyclopentenone prostaglandins suppress activation of microglia: Down-regulation of inducible nitric-oxide synthase by 15-deoxy-Delta(12,14)-prostaglandin J(2). Proc Natl Acad Sci U S A 1999, 96:4668-4673

34. Davies JQ, Gordon S: Isolation and culture of murine macrophages. Methods Mol Biol 2005, 290:91-103.

35. Zhang $X$, Goncalves $R$, Mosser DM: The isolation and characterization of murine macrophages. Curr Protoc Immunol 2008, Chapter 14:Unit 14.1 doi:10.1002/0471142735.im1401s83.

36. Pino PA, Cardona AE: Isolation of brain and spinal cord mononuclear cells using percoll gradients. J Vis Exp 2011, 48:2348.

37. Bachstetter AD, Norris CM, Sompol P, Wilcock DM, Goulding D, Neltner JH, St Clair D, Watterson DM, Van Eldik LJ: Early stage drug treatment that normalizes proinflammatory cytokine production attenuates synaptic dysfunction in a mouse model that exhibits age-dependent progression of Alzheimer's disease-related pathology. J Neurosci 2012, 32:10201-10210.

38. Butovsky O, Jedrychowski MP, Moore CS, Cialic R, Lanser AJ, Gabriely G, Koeglsperger T, Dake B, Wu PM, Doykan CE, Fanek Z, Liu L, Chen Z, Rothstein JD, Ransohoff RM, Gygi SP, Antel JP, Weiner HL: Identification of a unique TGF-beta-dependent molecular and functional signature in microglia. Nat Neurosci 2014, 17:131-143.

39. Goldmann T, Wieghofer $P$, Müller PF, Wolf Y, Varol D, Yona S, Brendecke SM, Kierdorf K, Staszewski O, Datta M, Luedde T, Heikenwalder M, Jung S, Prinz M: A new type of microglia gene targeting shows TAK1 to be pivotal in CNS autoimmune inflammation. Nat Neurosci 2013, $16: 1618-1626$

40. Mizutani M, Pino PA, Saederup N, Charo IF, Ransohoff RM, Cardona AE: The fractalkine receptor but not CCR2 is present on microglia from embryonic development throughout adulthood. J Immunol 2012, 188:29-36.

41. Darragh J, Ananieva O, Courtney A, Elcombe S, Arthur JS: MSK1 regulates the transcription of IL-1 ra in response to TLR activation in macrophages. Biochem J 2010, 425:595-602

42. Ananieva O, Darragh J, Johansen C, Carr JM, Mcllrath J, Park JM, Wingate A, Monk CE, Toth R, Santos SG, Iversen L, Arthur JS: The kinases MSK1 and MSK2 act as negative regulators of Toll-like receptor signaling. Nat Immuno/ 2008, 9:1028-1036

43. Kim C, Sano Y, Todorova K, Carlson BA, Arpa L, Celada A, Lawrence T, Otsu K, Brissette JL, Arthur JS, Park JM: The kinase p38 alpha serves cell type-specific inflammatory functions in skin injury and coordinates pro- and anti-inflammatory gene expression. Nat Immunol 2008, 9:1019-1027.

44. Bachstetter AD, Watterson DM, Van Eldik LJ: Target engagement analysis and link to pharmacodynamic endpoint for a novel class of CNS-penetrant and efficacious p38alpha MAPK inhibitors. J Neuroimmune Pharmacol 2014, 9:454-460.
45. Xing B, Bachstetter AD, Van Eldik LJ: Deficiency in p38beta MAPK fails to inhibit cytokine production or protect neurons against inflammatory insult in in vitro and in vivo mouse models. PLoS One 2013, 8:e56852.

46. Xing B, Bachstetter AD, Van Eldik LJ: Inhibition of neuronal p38alpha, but not p38beta MAPK, provides neuroprotection against three different neurotoxic insults. J Mol Neurosci 2014, [Epub ahead of print].

47. Chakravarty S, Herkenham M: Toll-like receptor 4 on nonhematopoietic cells sustains CNS inflammation during endotoxemia, independent of systemic cytokines. J Neurosci 2005, 25:1788-1796.

48. Engström L, Ruud J, Eskilsson A, Larsson A, Mackerlova L, Kugelberg U, Qian H, Vasilache AM, Larsson P, Engblom D, Sigvardsson M, Jönsson J, Blomqvist A: Lipopolysaccharide-induced fever depends on prostaglandin E2 production specifically in brain endothelial cells. Endocrinology 2012, 153:4849-4861

49. Chen Z, Jalabi W, Shpargel KB, Farabaugh KT, Dutta R, Yin X, Kidd GJ, Bergmann CC, Stohlman SA, Trapp BD: Lipopolysaccharide-induced microglial activation and neuroprotection against experimental brain injury is independent of hematogenous TLR4. J Neurosci 2012, 32:11706-11715.

50. Quan N: Immune-to-brain signaling: How important are the blood-brain barrier-independent pathways? Mol Neurobiol 2008, 37:142-152.

51. Laflamme N, Lacroix S, Rivest S: An essential role of interleukin-1 beta in mediating NF-kappa B activity and COX-2 transcription in cells of the blood-brain barrier in response to a systemic and localized inflammation but not during endotoxemia. J Neurosci 1999, 19:10923-10930.

52. Saraiva M, O'Garra A: The regulation of IL-10 production by immune cells. Nat Rev Immunol 2010, 10:170-181.

53. Bluthe RM, Castanon N, Pousset F, Bristow A, Ball C, Lestage J, Michaud B, Kelley KW, Dantzer R: Central injection of IL-10 antagonizes the behavioural effects of lipopolysaccharide in rats. Psychoneuroendocrinology 1999, 24:301-311.

54. Di Santo E, Adami M, Bertorelli R, Ghezzi P: Systemic interleukin 10 administration inhibits brain tumor necrosis factor production in mice. Eur J Pharmacol 1997, 336:197-202.

55. Bethea JR, Nagashima H, Acosta MC, Briceno C, Gomez F, Marcillo AE, Loor K, Green J, Dietrich WD: Systemically administered interleukin-10 reduces tumor necrosis factor-alpha production and significantly improves functional recovery following traumatic spinal cord injury in rats. J Neurotrauma 1999, 16:851-863.

56. Krzyszton CP, Sparkman NL, Grant RW, Buchanan JB, Broussard SR, Woods J, Johnson RW: Exacerbated fatigue and motor deficits in interleukin-10 deficient mice after peripheral immune stimulation. Am J Physiol Regu Integr Comp Physiol 2008, 295:R1109-R1114

57. Norden DM, Fenn AM, Dugan A, Godbout JP: TGFbeta produced by IL-10 redirected astrocytes attenuates microglial activation. Glia 2014, 62:881-895.

58. Pils MC, Pisano F, Fasnacht N, Heinrich JM, Groebe L, Schippers A, Rozell B, Jack RS, Muller W: Monocytes/macrophages and/or neutrophils are the target of IL-10 in the LPS endotoxemia model. Eur J Immunol 2010, 40:443-448

59. Guma M, Hammaker D, Topolewski K, Corr M, Boyle DL, Karin M, Firestein GS: Antiinflammatory functions of p38 in mouse models of rheumatoid arthritis: advantages of targeting upstream kinases MKK-3 or MKK-6. Arthritis Rheum 2012, 64:2887-2895.

60. Arthur JS: MSK activation and physiological roles. Front Biosci 2008 13:5866-5879.

61. Ehlting C, Ronkina N, Böhmer O, Albrecht U, Bode KA, Lang KS, Kotlyarov A, Radzioch D, Gaestel M, Häussinger D, Bode JG: Distinct functions of the mitogen-activated protein kinase-activated protein (MAPKAP) kinases MK2 and MK3: MK2 mediates lipopolysaccharide-induced signal transducers and activators of transcription 3 (STAT3) activation by preventing negative regulatory effects of MK3. J Biol Chem 2011, 286:24113-24124.

\section{doi:10.1186/s12974-014-0175-6}

Cite this article as: Bachstetter et al:: The p38alpha mitogen-activated protein kinase limits the CNS proinflammatory cytokine response to systemic lipopolysaccharide, potentially through an IL-10 dependent mechanism. Journal of Neuroinflammation 2014 11:175. 